Paidéia, 2001, 11(20), 11-26

\title{
A IMAGINAÇÃO DO OUTRO: INTERSECÇŌES ENTRE PSICANÁLISE E HIEROLOGIA ${ }^{1}$
}

\author{
José Francisco Miguel Henriques Báirrão ${ }^{2}$ \\ FFCLRP-Universidade de São Paulo
}

\begin{abstract}
RESUMO: Neste artigo comparam-se as contribuições para o estudo do imaginário e da alteridade de dois pensadores franceses, próximos pela época em que viveram e pela influência da fenomenologia em suas obras: o psicanalista Jacques Lacan e o filósofo e islamólogo Henry Corbin. O objetivo é contribuir para o desenvolvimento de um modo de investigação psicológica do imaginário religioso, que evite o reducionismo. Conclui-se que, na medida em que a vivência do sagrado se mostra indissociável de uma revelação do sujeito que a experimenta, o modo próprio do acontecer religioso convida a uma escuta do seu sentido numa perspectiva psicológica.
\end{abstract}

Palavras-chave: Psicanálise, religião, alteridade, imaginário, Psicologia Social

\section{THE IMAGINATION OF THE OTHER: INTERSECTIONS BETWEEN PSYCHOANALYSIS AND HIEROLOGY}

\begin{abstract}
This article compares the contributions to the study of the imaginary and otherness made by two French thinkers, close one to each other due to the epoch in which they lived and the influence of phenomenology in their works: the psychoanalyst Jacques Lacan and the philosopher and specialist on Islamic religion Henry Corbin. The objective is to contribute to the development of a method of psychological research which could avoid reductionism. It is concluded that, as the experience of the sacred cannot be dissociated from the revelation of the one who experiences it, the specific way of the religious event invites to listen its meaning from a psychological perspective.
\end{abstract}

Key-words: Psychoanalysis, religion, otherness, imaginary, Social Psychology

Os interessados em pesquisar através de uma perspectiva psicológica o imaginário social, consubstanciado em religiões populares, enfrentam o desafio de estudar fenômenos intrínseca e essencialmente sociais e psíquicos, mas também religiosos, e é-lhes apresentado o risco de incorrer em reducionismo (o perigo de achatá-los ou eliminar alguma das suas dimensões). Se a opção para os conhecer for destruir a sua complexidade, legitimamse críticas não apenas epistemológicas, mas também fundamentalmente éticas. $O$ resultado a que se chega é uma caricatura de conhècimento, cuja verda-

${ }^{1}$ Artigo recebido para publicação em agosto de 2001; aceito em fevereiro de 2002

${ }^{2}$ Endereço para correspondência: José Francisco Miguel Henriques Bairrão, Depto de Psicologia e Educação, Faculdade de Filosofia, Ciências e Letras de Ribeirão Preto-USP, Av. Bandeirantes, 3900, Monte Alegre, Ribeirāo Preto, SP, CEP 14040-901, E-mail jfbairrao@ffclrp.usp.br deira motivação é estabelecer uma relação de poder a serviço de fins totalmente alheios ao saber. Por outro lado, é importante não se impedir o aprofundamento da investigação psicológica em âmbitos, como a vivência religiosa, nucleares à pessoa humana e fundamentais para seu conhecimento. Como proceder para encontrar uma forma de produzir conhecimento em psicologia social que não se reduza a uma forma de rapina destruidora, desconhecedora, mas que também não se paralise ante a complexidade do assunto a estudar?

Ou seja, como superar o impasse entre reducionismo e impedimento? Como sair da dicotomia entre a impostura do psicologismo e o charlatanismo da mistificação em psicologia, comum quando a censura se desloca dos efeitos sobre o objeto para a superficialidade e inconseqüência do achatamento da investigação psicológica a prévios 
platôs da vivência religiosa?

A complexidade do assunto recomenda que se proceda a uma investigação interdisciplinar, no intuito de elaborar um procedimento à altura do problema, e é para isso que se recorre ao estudo comparativo de dois pensadores tão próximos e tão distantes como o psicanalista J. Lacan e o filósofo e islamólogo $\mathrm{H}$. Corbin, referências importantes nas áreas da psicologia refinada em psicanálise e do estudo do sagrado que não se detenha em superficial propaganda religiosa.

Ambos fortemente enraizados no que se poderia chamar de tradição fenomenológica francesa, aparentemente se distanciam pelo fato de o primeiro refletir algo tão "moderno" e "ocidental" como o inconsciente psicanalítico, e o segundo, apesar da tradição espiritual do Ocidente também lhe ter interessado, se debruçar principalmente sobre pensadores "antigos" e "orientais" (filósofos, poetas e místicos muçulmanos). Mas a obra de Corbin oferecenos um modo muito contemporâneo de refletir a alteridade e o imaginário, já tornado clássico, em boa parte por empiricamente estar embasada numa tradição cultural que intensa e longamente os meditou, e à qual a humanidade deve uma rica tradição poética. Interessa-nos o valor heurístico das suas contribuições para os fins da investigação psicossocial de fenômenos religiosos.

Como o que nos importa é estabelecer uma plataforma útil para o desenvolvimento de pesquisas nas quais interessa dar voz a sentidos presentes e memórias abafadas do sujeito social, e não tomar partido a favor ou contra esta ou aquela psicologia ou religião, não se presume fazer um estudo exaustivo e meticuloso dos dois pensadores, nem muito menos acompanhá-los em todas as implicações das suas teses.

\section{Introdução}

Lacan e Corbin são próximos e distantes. São próximos por serem contemporâneos e por participarem da mesma ambiência intelectual (a fenomenologia francesa, cada um de uma maneira própria e criativa). Assemelham-se também pela relativa heterodoxia nos seus respectivos meios. São personalidades que, mesmo quando não polêmicas, inspiram polêmicas. As suas obras alteraram definitivamente o panorama dos seus campos de saber. Lacan forçou a psicanálise a se repensar e levou às últimas conseqüências uma reflexão epistemológica sobre a psicologia, que originalmente foi uma crítica às versões não fenomenológicas da disciplina, mas culminou numa denúncia ética do cientificismo em ciências humanas, cujos resultados, mesmo que não integralmente aceites, merecem ser refletidos. E Corbin retificou a história da filosofia, recuperando uma parcela fundamental da contribuição persa e islâmica. Inevitavelmente, ao fazê-lo, incomodou teólogos dogmáticos e tradicionalistas de diversas religiões, não os impedindo de repetir os mesmos argumentos contra os heréticos que estudou de uma maneira tão apaixonada, mas certamente impedindo-os de voltar a fazê-lo de uma maneira muito simplista.

Para a presente finalidade, interessa a coincidência de pensarem com muita finura a problemática do imaginário e da alteridade, em permanente diálogo com a fenomenologia e mesmo pelo relativo abandono desta referência. Mas, sobretudo, importa o fato de o fazerem de perspectivas distintas: a psicológica e a religiosa (o que com eles se busca são precisamente pistas para um tratamento interligado, não redutor, destas duas dimensões da complexidade humana).

Fazem-no por perspectivas distintas, simetricamente opostas. O psicanalista enfoca a temática a partir do eu, do sujeito. Corbin parte da perspectiva do Outro, algo psicanaliticamente inconcebível, mas justificável no campo de estudos a que se dedica.

Outro aspecto de aproximação digno de nota é que ambos, longe de meramente especulativos, abordam a temática do imaginário e da alteridade de forma empírica. O psicanalista interessa-se pela loucura (enquanto possibilidade inerente ao humano) e o hierólogo examina na sua irredutibilidade a revelação do sagrado, por meio, principalmente, do testemunho de místicos. Algures Lacan distingue-as, apontando que falta no delírio o que sobra no místico: a presentificação de uma alteridade efetiva. $\mathrm{Na}$ loucura há uma comprovação da perda do Outro, na mística há o encontro com uma Presença, mesmo que pouco ou nada se possa saber nem dizer com clareza desse encontro. 
Além disso, há uma finura de análise psicológica - no sentido filosófico do termo - no tratamento da manifestação do sagrado em Corbin, bem como por sua vez Lacan $(1975,71)$ sempre teve interesse na religião e se mostrou intrigado com os místicos, a ponto de sistemática e reiteradamente recomendar a sua leitura e chegar a se equiparar a eles $^{3}$. De certa forma, o estudo de Corbin direcionase para acatar esta recomendação, o que este autor faz, de maneira bastante interessante.

A dimensão "empírica" das suas obras (tão empírica quanto Deus, a imaginação e o inconsciente o possam ser) talvez seja o segredo da longevidade destes pensadores num século de cultura francesa marcado por modismos e rápidas substituições. Ambos atravessaram o seu século e são indubitavelmente, nos seus campos, referências internacionais.

De início, fenomenólogos têm em comum o fato de valorizarem a compreensão e de, embora obviamente em acepções distintas, a atribuírem ao Outro. É o Outro que compreende. O psicanalista faz parte do inconsciente, está compreendido pelo outro. E o Outro, concebido Deus, necessariamente é compreensivo.

Ambos inspiram a levar em conta e mesmo a privilegiar a atribuição ao outro da compreensão das pesquisas desenvolvidas em ciências humanas e, no limite, justificam a inclusão, na forma da participação, do pesquisador na comunidade estudada (algo ética e epistemologicamente importante para um desenvolvimento profundo e sadio do conhecimento em psicologia social).

Assemelham-se igualmente por criticarem ferozmente a psicologia cientifica, mais particularmente a sua contemporânea, pelo viés da fenomenologia. Supõem-na um resquício, indevido, da destruição da metafísica. Lacan diz que o entendimento da psicologia via faculdades fazia sentido quando se admitisse a alma. Fora disso, não. Corbin pensa identicamente, mas vai além, responsabilizando os metafísicos ocidentais, e especialmente a teologia de Nicéia, pela tragédia da morte de Deus e pela extinção do habitat da alma.

\footnotetext{
? "Estas jaculatórias místicas não são nem palavrório nem verborragia, sāo em suma o que se pode ler de melhor - aí acrescentar OS Escritos de Jacques Lacan, porque são da mesma ordem".
}

Se a época hoje decreta que Deus está morto, poucos se dariam conta de que isso aconteceu porque Ele nasceu (encarnou). Ao retirá-lo do âmbito do imaginário para achatá-lo em realidade histórica e física, abre-se o caminho para atrelar a teologia à sociologia e reduz-se a aparição à ilusão, destruindo-se o "lócus" existencial possível da alma e de Deus $^{4}$. Esta óbvia "heresia" corbiniana (do ponto de vista de teologias oficiais), é de grande interesse científico, pois é ela que vai permitir-lhe valorizar e estudar o imaginário, auxiliando-nos a entendê-lo.

\section{Convergências e diferenças entre Lacan e Corbin}

A imagem interessa aos dois autores e vai ter um destaque epistemológico e ontológico no pensamento de ambos. Para Corbin, o imaginário, que prefere denominar de Imaginal, é um mundo intermediário entre o inteligível e o sensível, imprescindível $\mathrm{e}$ indevidamente desconsiderado no Ocidente. Para Lacan, é um dos célebres três registros, inseparáveis (simbólico, imaginário e real), sendo que para nenhum dos dois conta como ilusão (na acepção de falsidade).

A reflexão corbiniana, útil para todos os interessados no estudo do sagrado e, aposta-se, importante também para a psicologia, dialoga com um universo religioso específico. Corbin é um islamólogo. O islamismo é uma espécie de além interno à espiritualidade semítica judaico-cristã. Não é homogêneo. Corbin dedicou-se especialmente ao estudo dos que consideram imprescindível um trabalho hermenêutico sobre o sentido literal do texto: místicos sufis e xiitas, muitas vezes com uma cultura islâmica não exclusivamente árabe. $\mathrm{O}$ islamismo apresenta-se como a derradeira revelação monoteísta, uma espécie de "upgrade" da espiritualidade semita, que se pretende definitiva. Compreende o judaísmo e o cristianismo, reinterpretando-os, muitas vezes, segundo nuances teológicas abandonadas na historia dessas religiões. Baseia-se em relatos da vida do Profeta Maomé (hadith), alguns deles entendidos como diretamente inspirados por Deus (hadith

\footnotetext{
${ }^{4}$ Para Corbin, entusiasta da teologia negativa, o Deus Abscôndito, incognoscível e inefável, faz-se aparecer à medida (da imaginação) humana, na forma de outros, Seus mensageiros, reveladores e hermeneutas fundamentais do Insondável (Anjos, Profetas e Imãs).
} 


\section{José Francisco Miguel Henriques Bairrão}

qodsi), mas ocupa lugar de destaque na sua literatura o "Alcorão", compilação da fala de Deus, por intermédio do Anjo da Revelação, Gabriel, que o dita ao profeta Maomé.

O Alcorão inteiro pretende ser a enunciação desse Outro, transcendente ao humano. Pronunciase sobre muitas coisas previamente tocadas pelas Revelações anteriores. Contém inúmeras referências a personagens da epopéia espiritual semita, previamente conhecidos por meio de versões anteriores das suas proezas.

Importa para os nossos fins, muito, este estatuto sagrado da sua escrita. Se de uma perspectiva psicológica contaria entendê-lo como produção sintomática do psiquismo do cidadão árabe Maomé, perturbado por "visões" e "delírios" que também teriam afetado antecessores como Moisés e Cristo, não é este o campo em que o fenômeno se propõe em sua verdade, sendo necessário destruí-lo para recuperá-lo como ilustração psicopatológica. É exatamente este tipo de desrespeito aos dados que se deve evitar em psicologia, mas sem impedir esta ciência de, pela sua perspectiva, se pronunciar sobre a experiência religiosa.

Para devidamente se apreciar o que está em jogo, apresentam-se dois textos. Uma passagem dos ditos do Alcorão vertida para o português (extraída da Sura 24, intitulada A LUZ) e uma tradução aproximada de uma frase de Lacan:

"35. Deus é a luz do Céu e da Terra. A similitude da sua luz é de um nicho onde está uma lâmpada. A lâmpada está num vidro. $O$ vidro é como uma estrela brilhante. Esta lâmpada é acesa de uma árvore abençoada: a oliveira, que não é do Oriente nem do Ocidente, cujo azeite brilha por si mesmo, embora não seja tocado pelo fogo. Luz sobre luz. Deus guia para a sua Luz a quem quer. $E$ Deus fala aos homens com alegorias porque ele é conhecedor de todas as coisas".

36. Esta lâmpada encontra-se nas casas que Deus permitiu que fossem exaltadas, e onde o seu nome é recordado. Lá oferecem preces ao Senhor de manhã e ao entardecer." (Williams, 1980)
"O inconsciente não é subliminar, fraca claridade. É a luz que não deixa seu lugar à sombra, nem se insinuar o contorno. Representa a minha representação lá onde ela falta, lá onde eu sou apenas uma falta do sujeito." (Lacan, 1968, p.36)

Ambas falam de luz, de um sobrepujamento de luz superlativo. Mas o primeiro se propõe a ser uma auto-explicitação de Outro, Deus, pela alegoria da luminosidade, de uma maneira ofuscante. Esta alusão ao Outro, Deus, na forma de luz, é praticamente universal e a tradição semita a conhece anteriormente, por exemplo, na forma da sarça ardente que dita as Leis a Moisés e na das Línguas de Fogo do Pentecostes.

Aqui, esse numinoso ígneo se explicita por meio da sua antropomorfose à medida humana de um Mensageiro, Gabriel, que enquanto Anjo é de outra natureza que a humana. "Psicologizações" são possíveis, mas destroem o modo como o fenômeno se apresenta, desconhecem a estrutura e o campo de sentido em que se propõe.

O segundo é uma tentativa de falar de Outro lugar do eu. Revelá-lo numa posição em que "ele" está, o sujeito "é", sem (se) saber. A luz e a visão, intensamente inseparáveis da pulsão escópica, relacionadas ao sujeito do conhecimento, à vidência e à evidência cognitiva, são formas psíquicas efetivas de se presentificar, se indiciar, o real do sujeito.

Portanto, a diferença está menos na temática da luminosidade, e mais no ângulo de onde se a trata. Se o sujeito é outro para si, não necessariamente o Outro é sujeito, embora de algum modo este lá se encontre. Pois embora no Outro se encontre eu, e embora o Outro seja condição de interpelação do sujeito e a forma da sua manifestação estar à medida do sujeito, isso não autoriza a propor que o Outro se reduza ao que é significante e significativo do sujeito. Mas, por outro lado, nada impede que, cautelosamente, se o trate nessa perspectiva, por ser da natureza do Outro, Transcendente, se presentificar como espelho do eu. Portanto, na medida em que se manifesta como instância reveladora da alma, o Outro como que se apresenta como um parceiro útil no estudo e aprofundamento da psicologia, em vez de um impedimento. 
Lacan tinha razão. Vale a pena ler os místicos, têm o que ensinar ao psicólogo e ao psicanalista.

Mas antes de esclarecer o que com eles se aprende, é imprescindível esboçar uma sumária introdução dos conceitos de outro e de imagem, de uma maneira suficientemente ampla para caber aos dois pensadores ${ }^{5}$.

O que é Outro? Para efeito deste estudo, tudo o que não é eu, mas interpela. É condição de possibilidade de qualquer interlocução.

É sempre o que se apresente como interlocutor, implícito, fundamental. Por isso não tem um conteúdo fixo. Pelo contrário, "epifaniza-se" ou concretiza-se a cada momento em outros particulares, às vezes humanos. Ou seja, assume uma forma para o sujeito, um rosto, e é esta imagem do outro, ou de si refletido no outro, que será a imagem que aqui nos importa.

O imaginário que nos interessa, cuja propriedade principal é a especularidade, é o relativo à aparição do Outro, seja lá o outro quem for. Tanto para Corbin como para Lacan, o sujeito tem de ser pensado na sua interdependência com o seu Outro e este outro "imagina-se" concretamente.

A alteridade especifica-se conforme os campos e as relações que estejam em jogo. Freqüentemente, o Outro fundamental determina-se como Deus. Mas também pode ser "eu" além da minha compreensão, um alvo ou referência da intenção comunicativa, um interlocutor, ou o que interliga o horizonte do dizer.

Fora da interpelação com um sujeito, Outro Absoluto, é inacessível, impossível, Abscôndito; ou permanece mera virtualidade, condição estrutural de constituição, de atualização, a cada momento, de uma forma presente do Outro, uma imagem, da qual vai depender, muito, o "eu".

Há muitas semelhanças no tratamento desta díade, "eu" e "outro", pelos dois autores, a ponto de por vezes se sugerirem influênicias (Lacan sempre recomendou a leitura da temática de Corbin e menciona-o duas vezes no sétimo ano do seu seminário).

\footnotetext{
s O que se adianta obviamente é precário e esquemático, mas serve como um ponto de apoio, suscetível de posterior relativização, evitando que se pressuponham sabidas as noções que vão estar em pauta.
}

Divergem, porém os lugares de onde é tratada. O psicanalista parte do eu, e da sua dependência de um Outro, que não pode garantir. O hierólogo parte do Outro que se manifesta garante do sujeito, à medida das suas possibilidades. O Outro alcança o sujeito, mas o sujeito não alcança o Outro, para além da mensagem, discursiva, imagética, que dele recebe, e por isso vacila, duvida...

Se o psicanalista sai do seu papel de revelador do sujeito por meio do Outro, incorre em impostura. Mas Corbin, por partir do Outro enquanto revelação de autoria de Outro, outro mesmo, encontra-se com uma apresentação do fenômeno da alteridade e da imaginação estruturalmente muito distinta. Não obstante, para ambos, o Outro é, por assim dizer, como que uma possibilidade transcendental de toda e qualquer situação de alteridade.

Lacan admite que, no limite, o "seu" Outro, resumido ao esqueleto da significância, que não se garante a si mesmo, enquanto Verbo, virtualmente seria Deus (o conjunto praticamente infinito de todos os enunciados possíveis e efetiváveis no horizonte da combinatória simbólica). Para ele, o Outro, como insegura garantia da Palavra, necessária ilusão transcendental, é como que a casca vazia do que teria sido o ovo do Deus cartesiano.

Para Corbin, o Outro que importa é Deus, independentemente da forma da sua epifania (isto é, da Imagem em que se revele). Não o Deus dos filósofos e dos teólogos, facilmente "escalpejável" em conceito ao serviço de divagações especulativas, mas um Deus que se faz presente, que se faz ver (Corbin, 1977, p. 178)

A desventura da psicanálise prende-se ao fracasso em poder reduzir o inconsciente a algo que apareça na consciência. Para Lacan inelutavelmente algo escapa ao sujeito e isso o deixa em falta, o que leva a uma crise do conhecimento e a um agnosticismo trágico. O psicanalista depara-se com uma precariedade do humano vinculada à falta de garantias do Outro, para além da palavra que o afirma.

Mas, e se, a partir da fenomenologia, se levar a sério a estrutura enunciativa em que o Outro fala?

Com Corbin a situação é outra. Se para a psicanálise há sempre um falso encontro, o que se acha é sempre outra coisa (dado o inconsciente), em 


\section{José Francisco Miguel Henriques Bairrão}

Corbin o achado não é mero devaneio subjetivo presentificador de ausências. É encontro com uma presença.

Deste modo, para um psicanalista, a hierologia corbiniana presta-se a ilustrar o desenvolvimento lógico da hipótese de que a verdade não falte no seu lugar (algo incompatível com o dispositivo analítico, campo de meias verdades). Apresenta-se como a oportunidade de uma meditação sobre a alteridade, que admitisse a transposição do agnosticismo. Mostra-nos como as coisas se passariam se realmente Outro se apresentasse.

As diferenças não são as aparentemente óbvias. Para ambos, conhecer o Outro é conhecer a si, no limite, psicanaliticamente algo impossível. Para os dois está em pauta o estatuto do "si" e a indissociabilidade entre eu e outro.

No conjunto a contraposição das reflexões sobre a alteridade a partir destes vieses simétricos proporciona importantes subsídios metodológicos para se alcançar um entendimento integrado da singularidade de cada subjetividade interligada ao seu contexto sócio-cultural e especialmente religioso.

Foi com esse propósito que se apresentaram estas reflexões, introdução cerrada e sumária de alguns pontos capitais, necessários para esmiuçar e desenvolver a comparação entre as perspectivas (bem) representadas pelos dois autores, a que ora se vai proceder.

Primeiramente, vai fazer-se um apontamento biográfico que permita situá-los. Em seguida, dedicar-se-á atenção ao esclarecimento das suas concepções epistemológicas e atitudes relativamente à fenomenologia e, finalmente, examinar-se-ão mais sistematicamente as suas concepções de imagem e de imaginário (imaginal, para Corbin) e as suas posições relativamente à alteridade do compreendido, para mostrar como e por que, neste ponto, são levados a posições próximas e simétricas, dada a diferença de enfoque das suas respectivas perspectivas. Esta sequiência entremeará cada um dos autores.

Para concluir espera-se, com base nas contribuições de ambos, estabelecer subsídios que permi-

\footnotetext{
- "O Deus de que fala aquele que não é testemunha ocular, é um $<<a u-$ sente >; eles não se viram. É por isso que o Deus de um dogmático nåo pode vir em sua ajuda contra o de um outro; os antagonistas não podem nem vencer nem convencer, não podem senão separar-se bastante descontentes um com o outro"
}

tam à psicologia e ao fenômeno religioso conviverem não ofensivamente. Ou seja, almeja-se que, a partir da Imaginação do Outro - quer entendida na perspectiva do que o Outro, suposto sujeito, imagina; quer na de que o eu, mesmo supra ou inconscientemente, imagine o Outro - obter elementos para um tratamento rigoroso e interdisciplinar da religiosidade, de um ponto de vista psicológico não redutor, mas também não escamoteador das dimensões e das implicações psíquicas do fenômeno religioso.

\section{Duas perspectivas do Outro}

Lacan, psiquiatra marcado pela ambiência filosófica francesa, tenta, nas pegadas de Politzer, chegar a uma redescrição fenomenológica da psicanálise, ao tentar re-significar a metapsicologia. $\mathrm{O}$ inconsciente, previamente entendido como imago inconsciente, aparece-lhe como irredutivel, e a partir daí desiste de pensar a psicanálise como ciência psicológica, re-situando-a como uma prática de fala, rigorosa, mas sem valor cognitivo. Desiste do conhecimento, preservando, como base fenomenal da não possessão cognitiva do objeto referenciado pela representação inconsciente, a indicação do seu lugar na palavra. Envereda por reflexões de cunho ético e ontológico e chega a contrapor a psicanálise à religião, tomando-a como outro fundamental da psicanálise.

A reiteração à exaustão da idéia de falta de garantia do encontro com o outro e consigo mesmo, a perenidade do sujeito enquanto dividido são motes do seu pensamento. Ao destaque dado à palavra, entendida como alteridade, mas também como a concretude possível da experiência psíquica intersubjetiva, não é estranha a importância da sua prévia formação fenomenológica. Afirmava que as implicações do seu ensino só ficariam claras, largos anos depois.

Tal como Corbin, que foi o primeiro tradutor francês de Heidegger, traduziu este filósofo e manifestou vívido interesse pela sua obra.

Corbin também não foi um intelectual francês para consumo imediato. A sua obra, clássica entre especialistas, mas que não se tornou fenômeno mediático, ultrapassou o seu século e é exemplo de trabalho claro e sólido que veio para durar. $\mathrm{Da}$ sua 
trajetória intelectual, o autor ressalta a freqüência às conferências de Etienne Gilson sobre as traduções medievais de Avicena. Encantado, estudou árabe, e do árabe foi levado a aprender persa. Dirigiu a secção de ciências da religião da Escola Prática de Altos Estudos a partir de 1954, sucedendo a Louis Massignon, o qual teve um excepcional papel no rumo dos seus estudos e da sua vida (Corbin, 1985). Passou parte da sua vida e desenvolveu a sua carreira em diversos países do Oriente Médio (especialmente na Turquia e no Irão). Considerava-se um islamólogo que abordava a disciplina por um viés filosófico, embora a qualificação de hierólogo certamente não lhe desagradasse.

Segundo Corbin (1990), em 1908 foi proposto este neologismo pelo historiador belga Conde Goblet d'Alviella. Na realidade, o termo só era novo nas línguas contemporâneas, já existindo nos dicionários gregos. A nova denominação serviria para designar o estudo do sagrado. Porém, apesar de ter sido bem aceita, não alcançou muito sucesso e Corbin se interroga se na realidade isso não sucedeu por provavelmente a sua aceitação não ser meramente uma questão de nomenclatura, implicando em decisões cruciais para as chamadas ciências da religião. Diz o autor:

"Teria sido necessário, em primeiro lugar, tomar claramente consciência daquilo que se propunha. 1) Decidir se a hierologia podia se aplicar indiferentemente ao objeto religioso tal como o tinham captado - ou falhado - as diferentes escolas e métodos entre os quais se tinha partilhado a ciência das religiões no séc. XIX, ou se, ao contrário, se a hierologia postulava e indicava uma maneira de ver e de fazer ver que lhe fosse própria e que correspondesse enfim de maneira própria a esta região do ser que se denomina o Sagrado; 2) Teria sido necessário decidir se sob este nome podia-se continuar muito simplesmente a fazer sociologia ou etnologia - $e$ creio que estas duas últimas ciências doravante tão claramente constituíram seu objeto e mostraram o seu foco de interesse, que não deveria mais aí haver confusão possível; 3) Teria sido necessário decidir se a "ci- ência das coisas sagradas" teria verdadeiramente como tarefa explicar seu objeto por um esquema de causalidade aplicável indiferentemente noutros lugares e se ela devia se contentar com uma simples interpretação psicológica dos problemas essenciais; 4) Ou bem ainda se as suas pesquisas se identificariam pura e simplesmente com as da filologia; 5) Ou enfim se seu horizonte se confundiria pura e simplesmente como das pesquisas históricas, se ela não deveria apreender o seu objeto a não ser na forma da categoria do passado enquanto passado, se não haveria como esperar outra "objetividade" que não instituindo a ausência do "objeto", e se esta impessoal objetividade da ausência deveria autorizá-la a desconhecer o rigor que pode comportar uma ciência da presença." (Corbin, 1990, p. 21 e 22)

A região do ser relativa ao sagrado não poderia subsumir-se a nenhuma das outras disciplinas relativas ao humano, embora estas possam com ela conviver e trazer as suas contribuições.

Para Corbin, a indigência destas abordagens não era devida ao fato de se prenderem aos chamados dados positivos, mas ao fato de, supostamente, restringirem arbitrariamente estes a determinadas dimensões do ser, excluindo o campo do sagrado.

Objeções quanto à falsidade ou irrealidade desta região do ser são sumariamente descartadas pelo autor:

“... persuadamo-nos disto: se alguém é incapaz de distinguir um intervalo de quarta de um intervalo de quinta, não se o aconselhará a tentar uma carreira musical. Se um de vossos amigos não consegue captar o mecanismo das declinações, vós sorrireis ao ouvi-lo expressar altas ambições lingüísticas ou filológicas. Igualmente, reconheçamos que existe uma certa tonalidade do ser condicionando a percepção do objeto filosófico ou do objeto religiosos. Se dela se está privado é melhor ocupar-se de outra coisa. $O$ minimo que se pode dizer é que este postulado de simples honestidade foi 
freqüentemente ridicularizado e que as gentes mais fechadas ao objeto de que pretendiam se ocupar foram os mais intrépidos a formular julgamentos que só recaíam sobre elas mesmas". (Corbin, 1990, p. 11 e 12)

\section{Segundo Corbin :}

“... há várias ordens de realidade, às quais correspondem vários modos de dados e de "existência objetiva", modos irredutiveis uns aos outros, não dependentes uns dos outros. E não se pode alcançar uns e outros a não ser pela análise dos atos de consciência que a eles conduzem, e nos quais unicamente se pode manifestar a região do ser à qual eles tendem. Em suma, não se pode esperar falar de uma maneira sensata e convincente do objeto religioso a não ser colocando-se no interior da consciência religiosa e apelando aos critérios que lhe são próprios. Se não, não se aceitando este dado imediato do ser segundo o modo de existência que lhe é próprio, se se quer recorrer a critérios que the são estrangeiros, tudo remeter, por exemplo. ao tipo de existência empírica sensível, então cada vez que outra região do ser venha à luz, poder-se-á sair perguntando: "existe?" e só se lidará com fantasmas". (Corbin, 1990, p. 23)

Seria este o caso das várias formas de reducionismo, de que é caso exemplar e preocupante o psicologismo:

"Conceber por exemplo tal forma de estado vivido, tal função psíquica, através da qual e graças à qual se revela tal domínio privilegiado do ser, como sendo não mais o lugar e o órgão, o meio (médium) desta aparição, a forma deste fenômeno, mas como sendo elas exclusivamente a explicação do seu ser mesmo, a sua razão primeira e derradeira. Era em suma para uma psicologia que, muito repentinamente, não ousava mais pronunciar a palavra alma, antecipar sobre a conclusão: vejam, está explicado. Só era aquilo! Em vez do fenômeno, de uma epifania do ser, não se tinha com efeito diante de si a não ser um fantasma de ser." (Corbin, 1990, p.24)

Corbin concebe o psicologismo como uma tendência a esvaziar as imaginações do modo próprio da sua realidade. É a temática, que este autor sempre retoma, da deformação do imaginário como ilusão e falsidade (cuja ampla difusão o leva a propor o neologismo "imaginal"), como se a sua medida tivesse de ser a mesma que a da percepção sensível. Neste aspecto, está de pleno acordo com Lacan, que, além disso, sublinha que deste modo se esvazia o específico da psicologia (Lacan, 1966).

Ora, segundo Corbin, graças à fenomenologia, tal atitude é improcedente:

"Devemos à fenomenologia o poder considerar a maneira como o homem experimenta sua relação com o mundo, sem a reduzir a qualidade objetiva dos dados da percepção sensivel, nem limitar o campo do conhecimento verdadeiro e significativo às únicas operações do entendimento racional. Resgatados desembaraçados do impasse, aprendemos a recolher e a valorizar as intenções implícitas de todos os atos de consciência ou da transconsciência. Enunciar que a Imaginação (ou o amor, ou a simpatia, ou um sentimento em geral) faz conhecer, e faz conhecer um objeto que lhe é próprio, isso não tem mais o sabor de um paradoxo". (Corbin, 1977, p. 11)

O autor observa meticulosamente que, para podermos falar, por exemplo, de inquietações religiosas, precisamos admitir um sujeito religioso a que caibam estas inquietações, mesmo que estas possam pensar-se também por outras perspectivas. Concorda com Rudolf Otto quando este fala do sagrado como a priori. Admite-o como um ato transcendental (ato da consciência intencional), estruturalmente inseparável do termo correlativo que o significa, uma Presença transcendental, inseparável daquilo que ela torna presente (Corbin, 1990). E na sua opinião, é isto que faz uma certa miséria de outro "ismo" que deplora (o historicismo). 
Para ele não há como confundir hierologia com história das religiões, exatamente pelo procedimento típico do historiador, tentando, por exemplo, explicar os vestígios materiais de uma crença por motivos anteriores e estabelecer um fio com o que lhe sucede, criando uma narrativa alheia ao fato de que tais pensamentos precisaram de uma presença para existirem. Isto é, que as evidências históricas de uma experiência religiosa pressupõem a presença do numinoso que se apresentou daquela forma, e que o tempo deste não é o da cronologia. Pelo historicismo, a presença do sagrado, irredutível, tenderia a ser ignorada em prol de explicações que a partir de um elo oni-explicativo (por exemplo, as relaçōes econômicas), fariam tabua rasa da reconstrução, representação, da forma de vivência religiosa que se apresentou em dada época (Corbin, 1990).

Tal atitude é incompatível tanto com um estudo não redutivo do sagrado, quanto com a perspectiva metodológica fenomenológica, para a qual, segundo o autor, os modos de ser do sujeito pessoal e as regiões do ser que ele explora não podem dissociar-se.

Lacan, na sua época estritamente fenomenológica, vai afiançar identicamente a importância da fenomenologia nas ciências humanas (Lacan, 1966).

Ambos sugerem que, para poder conhecer, o estudioso tem de se colocar numa posição compatível com o horizonte de ser que vai ser estudado, sob pena de se mostrar incapaz de o descrever.

Corbin explicita-o, afirmando a importância de se colocar no interior da consciêncià religiosa, acessível à presença do sagrado, para poder se pôr na perspectiva correta ao seu estudo:

"Há uma polaridade entre o objeto que se mostra e aquele a quem ele se mostra. Para que o pesquisador dele possa falar por sua vez, é necessário que este objeto se mostre a ele, é necessário que umà nova polaridade se estabeleça". (Corbin, 1990, p. 105)

Templos, liturgias, dogmas, escrituras, etc., não assumem sentido hierológico se não forem enfocados correlativamente à evocação reapresentadora de uma alteridade fundamental, ine- rente à vivência que os suscitou.

É sempre a temática da Presença do Outro que está em pauta.

Importaria estabelecer um procedimento que, em lugar de argumentar racionalmente do efeito à causa, perceba nos dados o Doador destes dados. E para que isto se efetive, de algum modo Ele deve representificar-se no tempo presente da investigação (Corbin, 1990).

Desta forma, a fenomenologia, em si mesma, desdobra-se em ontologia. Percurso que Lacan é obrigado igualmente a percorrer desde que o seu intento de fundar uma psicologia rigorosamente concreta com base na psicanálise se vê frustrado pela impossibilidade de reduzir a noção de representação inconsciente a algo palatável ao gosto fenomenológico (Bairrão, 2000). A partir de então é levado a admitir que o inconsciente é, sem que se possa dizer o que é, refletindo a noção em âmbitos alheios ao conhecimento imediatamente ontológico.

Porém, fora esta semelhança, aqui os autores se distanciam. Para Lacan, o próprio conhecimento está comprometido, uma vez que nunca se sabe exatamente o que seria inconscientemente representado. A idéia de representação inconsciente obriga-o a admitir um sujeito igualmente inconsciente. Um "outro" que é "si mesmo", e que se assinala nas circunvoluções da linguagem, que é o que sobra de experiência fenomênica confiável (Bairrão, 1996).

Neste contexto, o que se marca é a ausência, e não uma Presença. O ser de que se trata em psicanálise é o que brilha no (vazio do) verbo ser (Lacan, 1966 , p. 520) ${ }^{7}$. A um só tempo signo da indeterminação do sentido e vazio imanente à palavra:

"O homem fala-ser, como disse, o que não quer dizer nada mais do que fala significante, com o qual a noção de ser se confunde" (Lacan, 1977, p. 7).

Lacan situa na linguagem, como ilusão necessária e imanente à dicção, o lugar Outro de um "Tu", testemunha do que se diga e de que se diga alguma coisa.

\footnotetext{
7 "Trata-se aqui deste ser que só aparece no clarão de um instante no vazio do verbo ser..."
} 
Subjacente ao ser o que realmente insiste é um dizer, que é um fazer o ser. Em cada aparência de presença apenas desponta o sujeito, dividido e perdido de si. A significância, enunciando sentido, "faz-me ser".

O Outro imperativo que "me" subjuga, outra coisa não é que "meu" querer. A alteridade como palavra, tão cultivada pela religião, só pode exprimir o desejo (Lacan, 1977, p. 11) ${ }^{8}$. Desejo do Outro, Outro no qual, em várias acepções, se pode reconhecer Deus.

A respeito deste, o psicanalista admite que...

“... não é tão fácil de eliminar como se crê, pois em realidade permanece estável no horizonte certamente em todos os casos de nossos pensamentos..." (Lacan, inédito) $)^{9}$.

Pois, dada a presença da palavra, sempre é cabível supor Outro, dicente e testemunha. Porém, em rigorosa coerência com a experiência da palavra possível à condição humana, da perspectiva de escuta do sujeito inconsciente, que é o seu recorte enquanto psicanalista, aponta corretamente que a palavra por si mesma, condição de garantias, não tem credenciais para garantir algum garante:

"Partamos da concepção do Outro como lugar do significante. Todo o enunciado de autoridade nâo tem aí outra garantia que não a sua própria enunciação, pois é vão que se o procure em um outro significante, o qual de nenhuma maneira poderia aparecer fora desse lugar... aforisticamente: não há Outro do Outro" (Lacan, 1966, p. 813).

Mas asseverar não haver Outro do Outro soa como uma garantia. Uma garantia da falta de garantias que, ela própria, não pode ser garantida.

A suspensão de juízos últimos sobre o Outro, intrínseca ao enfoque psicanalítico (circunscrito à imanência da palavra), é incompatível com qualquer certeza sobre o Outro, transcendente às condições da fala. E certamente por isso, reconduzido à "mo-

\footnotetext{
" "A psicanálise, é necessário dizê-lo... - é a forma moderna da fé, da fé religiosa"

${ }^{9}$ Lacan, seminário inédito intitulado D“Un Autre à l'autre registro da fala do dia $4 / 6 / 69$.
}

déstia" do seu ofício, Lacan suspende a tentação de fazer teologia anti-teológica, relativizando o seu aforismo (nos termos de uma prudência agnóstica):

"A falta da qual se trata é bem o que nós já tínhamos formulado: que não há Outro do Outro. Mas este traço do Sem-Fé da verdade será a ultima palavra que vale a pena dar à questão "que quer de mim o Outro?", sua resposta, quando nós, analistas, somos o seu porta-voz? Certamente não, e justamente pelo que o nosso oficio nada tem de doutrinal. Nós não temos de responder por nenhuma verdade última, especialmente nem a favor nem contra nenhuma religião". (Lacan, 1966, p. 818)

Psicanaliticamente perspectivado, o empenho em prol da existência de Deus reflete menos uma especial consideração pelo Criador do que a angústia da criatura com a falta de garantias em ser (Bairrão, 1996).

Se fosse possível garanti-Lo, poder-se-ia superar a cisão subjetiva, contra o que se ergue a experiência do inconsciente. Por sua vez, a negação da garantia não pode confundir-se com uma garantia da negação (do Outro), pois esta participa da mesma lógica de "ficcionar" garantias. $\mathrm{O}$ ateísmo é uma questão de teólogos, foge da alçada do psicanalista.

Em psicanálise, qualquer Outro suposto enunciante sempre se mostra (como) outro significante, não se revela sujeito absoluto. Deus, se o termo for de alguma valia, é a capacidade de conjunto da palavra de ter efeitos (Lacan, 1975, p. 77) ${ }^{10}$. Deus é (feito) verbo:

"O Outro, o Outro como lugar da verdade, é o único lugar, ainda que irredutivel, que podemos dar ao termo Ser Divino, de Deus para o chamar por seu nome. Deus é propriamente o lugar onde, se me permitem o jogo, se produz deus - deuser - dizer. Por um triz, o dizer faz Deus. $E$ enquanto se disser qual-

\footnotetext{
10 "Que o simbólico seja o suporte do que foi feito Deus, está fora de dúvida"
} 
quer coisa, a hipótese Deus estará lâ." (Lacan, 1975, p. 44)

Deus resume-se a uma ilusão incontornável, provocada pelo fato do sujeito, descentrado, não se reconhecer na enunciação; bem como por a arquitetura simbólica do enunciar e do enunciado figurar posições para Outro, interpelador, interlocutor, testemunha e artífice do sentido.

Embora reduzido à sintaxe e a palavras, não se confunda esta argumentação sobre Deus, que Lacan elabora para psicanalistas, com uma paradoxal espécie de "ateísmo cristão" ou "cristianismo ateu" (a estrutura feita carne, existência). Não pode por sua vez, nem pretende, propor-se como verdade total, supra-regional.

A situação de Corbin é completamente distinta, porque não herda o abismo da falta de garantias do eu pela perda do objeto, que condena o sujeito a mal se assegurar pela precariedade de uma palavra de que não tem garantia. Para Corbin, o Garante fazse presente. Basta, segundo as suas palavras,

“...<<salvar $>>$ o fenômeno religioso, quer dizer, deixá-lo mostrar-se tal qual ele é para aquele a quem se mostra, e sem o qual ele não se mostraria nunca". (Corbin, 1990, p. 105 e 106)

Do ângulo corbiniano não há necessidade, nem tem cabimento, fazer a leitura do imperativo da Lei do Outro como sopro do desejo, do sujeito, alimentando o campo simbólico em prol de uma recuperação de uma unidade mítica, para sempre perdida (conforme Lacan faz). O que é, assenta-se na Ordem do Outro: "Sê!" Mas tal imperativo não é perspectivado como relativo ao sopro subjetivo que anima e dá volume ilusório ao espantalho da alteridade. É o Outro em si mesmo que revela o assentamento do ser na sua Palavra (conforme a Criação segundo a Bíblia e o Alcorão). Deus é o Ato puro de ser, não se confundindo com um suposto ente supremo, forma medonha de idolatria, o "pecado" mais grave para um muçulmano. Neste aspecto, Corbin e Lacan concordam. O Outro não existe ${ }^{1}$.

${ }^{11} \mathrm{O}$ que, ao contrário do que uma leitura simplista poderia levar a supor, apenas indica que não existe uma "coisa" tal que seja Deus.
Mas em relação à exclusão garantida de um Outro garante da Palavra que por sua vez não se consubstancie noutra palavra, se logicamente isto cria e fundamenta o agnosticismo consubstancial à prática psicanalítica, do ponto de vista de uma perspectiva que não enfoque o logos a partir do sujeito, mas o admita pertinente a um Outro que se faz presente com e na Palavra, a situação é bem diversa. E um místico como Ibn'Arabi (citado por Corbin) pode afirmar:

" $<<E$ É Deus mesmo quem articula pela língua do seu fiel as palavras: Deus escuta aque le que o glorifica >>". (Corbin, 1977, p. 200)

Pode dizê-lo precisamente porque a sua perspectiva não é a do que o sujeito faz com a Palavra, com o Outro, mas a da presença do Outro na Palavra que se pronuncia pelo sujeito. Para Corbin é o Ser Divino que de fato é o sujeito ativo de todo o conhecimento de Deus. É ele que se pensa no pensamento que o intelecto humano tem de si, conforme o hadith qodsi

$"<<$ Eu sou doravante o olhar pelo qual ele vê, o ouvido pelo qual ele escuta, a mão com a qual ele apalpa, o pé com o qual ele anda, etc. >". (conforme Corbin, 1990, p. 152)

Provavelmente concordaria com Lacan quando este, como se viu, afirmava ser a psicanálise a forma contemporânea da fé religiosa, pois aquela acompanha o passo do destino da transcendência no Ocidente, a morte de Deus. Em vez de abrigar a aparição epifânica da divindade em formas à medida da aptidão do crente, perduradouras num tempo espiritual, cíclico, não cronológico, e noutro lugar que não o mundo sensível, o ocidente preferiu execrar o docetismo, compreendido como aparência degradadora da realidade, em vez de como epifania, Aparição ou Transparição (Corbin, 1977, 1990).

A Encarnação de Deus, entendida como o divino feito carne ${ }^{12}$, não poderia ter levado a outro resultado que não a uma extrema dificuldade para perceber o fenômeno do sagrado no âmbito que é

\footnotetext{
12 Sumariamente recusada no Alcorão, no qual na sura 112 (intitulada “A Fé Pura”), Deus é declarado Uno, não tendo gerado nem sendo gerado, portanto nem Pai nem Filho.
} 
pertinente à sua revelação, o Imaginal, excluindo-o da nossa civilização.

Contemporâneo e coerente, Lacan pôde expressar o seu ateísmo "light" em algum aforismo do tipo "Deus é inconsciente".

\section{Mística e psicologia}

Por outro lado, de modo algum uma forma de teísmo antiga e contemporânea, qual a corbiniana, em si mesma, implicaria numa renúncia ao saber psicológico e coagiria a não poder contar com as conquistas da psicanálise sobre a verdade do sujeito. Pelo contrário, estas, às vezes, perante um olhar contemporâneo, surgem antecipadas pelos místicos. Por exemplo, Shirazi, no "Livro da Teosofia do Trono", afirma:

"Tudo o que o homem imagina, tudo o que percebe em realidade, seja qual for esta percepção, inteligivel ou sensível, neste mundo ou no além, tudo isso constitui outras tantas coisas inseparáveis do seu eu essencial. Melhor dito, o que é para ele objeto de percep. ção é algo que existe em si mesmo, e não em algo alheio a ele". (Corbin, 1996, p. 189)

E a compreensão deste imaginário, sagrado mas "psicológico", correlativamente com um reconhecimento do enraízamento do sujeito no corpo (o que moderna e freudianamente se denominaria de pulsão) aparece na obra de outro autor, Kirmani, em "Kitab Irsad al-awamm":

"O paraíso do fiel crente é seu próprio corpo. Suas obras virtuosas... são suas árvores, seus rios, castelos e huries. $O$ tormento do ímpio não é nada mais do que o seu próprio corpo; suas más ações são suas fogueiras, monstros, serpentes, cães, dragões, etc." (Corbin, 1996, p. 245)

Anacronismos à parte, embora tão vertiginosas aproximações sejam perigosas e seja possível encontrar inumeráveis argumentos contrários à realização de comparações "selvagens" como esta, o fato é que, conforme Corbin bem sublinha, muitas vezes o relativismo histórico serviu para ratificar préconcepções projetadas no passado pelos contemporâneos. Só por si, não é garantia de virtude.

Os escritos falam por si, independentemente de quaisquer esforços para pressupor-lhes um significado anterior e projetá-lo no passado e no autor. Uma vez presentes pela escrita, as obras antigas atravessam o tempo, tanto para revelar-nos não caricaturalmente a sua época, como para dizer-nos alguma coisa que também faça um sentido contemporâneo, independentemente deste estar ou não contido no que se fantasie ter sido a intenção original do autor.

Compreendê-los é compreender-se com eles. Um leitor contemporâneo pode encontrar questões nossas, nestes psicólogos religiosos. Concebem o outro, e concretamente a forma manifesta de apresentação do Outro, como uma revelação do próprio sujeito a si mesmo, algo que é vital para a psicanálise e importante para nós.

Para eles o Deus que se manifesta, o Anjo, é o segredo da ipseidade, é o si de seu fiel, que opera nele e por ele. É um ponto de intermediação entre o eu e o objetal, sobre o que vale a pena refletir tendo em mente noções psicanalíticas como "objeto a" e fenômeno transicional.

Para Ibn'Arabi,

“< $<$ A forma que se mostra é a forma mesma
do que se recebe. Ao mesmo tempo é o que se
mostra (motajalli) e a quem se mostra
(motajallò laho) $>>"$ (Corbin, 1977, p. 153)

A mesma tese é literariamente ilustrada por outro autor, Attar, nos momentos finais da epopéia mística "A Linguagem dos Pássaros", que relata uma metafórica peregrinação destes animais alados, guiados pela poupa, em busca de uma ave divina, Simorgh. Apenas trinta são bem sucedidos. Em persa, Simorgh e trinta pássaros (si morgh) são homófonos.

Embora exista uma edição bem cuidada em português (Attar, 1987), acompanha-se (cita-se) Corbin e a sua versão:

“... esta exaltação no reconhecimento de si mesmo por um Outro em que se reconhece a si mesmo como em um espelho, Attar a des- 
creve em um episódio final que é um dos grandes momentos da literatura mística universal. $<<$ Neste momento, no reflexo do seu rosto, os si morgh (os trinta pássaros) viram a face do eternal Simorgh. Eles viram: era bem este Simorgh, sem dúvida alguma, este Simorgh era bem estes si-morgh. Então o espanto os fremia de vertigem. Eles se viam a si mesmos no total de si-morgh (trinta pássaros); e Simorgh era no total si-morgh. Quando eles voltavam seu olhar para simorgh, era bem este si-morgh que estava lá. Quando se contemplavam a si mesmos, era desta vez ainda si-morgh: E quando olhavam simultaneamente dos dois lados, Simorgh e si-morgh (os trinta pássaros) eram uma só e mesma realidade. Havia duas vezes Simorgh, e, no entanto, só havia uma; sim, uma só e no entanto várias $>>\ldots$

Eles nem tiveram necessidade de interrogar Simorgh servindo-se da linguagem para the rogar resolver o enigma. Seu estado de espanto interrogava por si mesmo, e receberam esta resposta:

$<<$ Minha majestade semelhante ao Sol é um espelho. Aquele que vem se ver neste espelho: corpo e alma, alma e corpo, aqui se vê por inteiro. Como vocês vieram si-morgh (trinta pássaros), vocês apareceram trinta (si) neste espelho. Que viessem quarenta ou cinqüenta pássaros. $O$ véu se levantaria igualmente diante deles! Viessem vós como uma multidão, igualmente se teriam visto a vós mesmos. [...]. Eu sou muito superior a simorgh, pois eu sou o essencial e eternal Simorgh. Abismai-vos pois em mim, a fim de vos encontrar a vós mesmos em mim...". (Corbin, 1977, p. 165 a 167)

Em síntese, do ponto de vista hierológico, Deus descreve-se a si mesmo por nós mesmos. A alma toma consciência de que ela vê Deus, não por ela mesma, mas por Ele próprio. O ser divino reflete-se e presentifica-se no coração de cada um. Coração que, segundo Corbin, na fisiologia mística é o órgão da imaginação: estaria para a imagina- ção como a mão para o corpo.

\section{A experiência do sagrado consente a análise psicológica}

Embora no estado de desvelamento o coração do gnóstico seja como um espelho no qual se reflete a forma microcósmica do ser divino, esta forma espelha o estado de ser do próprio humano que a vê.

Assim, não se veria porque não poderia constituir-se em base profícua para o entendimento do sujeito, ou que a sua abordagem por este viés implicasse imediatamente numa negação da sua dimensão de sagrado.

Afinal, cada imagem teofânica seria correlativa da forma de consciência à qual ela se mostra. Por isso,

“... o que a alma encontra e conhece é esta Imagem sua e sua própria Imagem. Esta Imagem que ela projeta e conhece é ao mesmo tempo a que ilumina e a que reflete as figuras à sua Imagem, figuras das quais, reciprocamente, ela constitui a Imagem...". (Corbin, 1996, p. 60)

Se a alteridade radical é incognoscível, a concentração do místico permite a sua aparição em uma medida reveladora do seu próprio eu e da sua própria necessidade. Este procedimento, que muitos tradicionalistas e fundamentalistas muçulmanos tentam apresentar como herético, autorizar-se-ia de uma célebre sentença sufi, também atribuída ao $1^{\circ}$. Imã do xiismo: <<Quem se conhece a si mesmo conhece o seu Senhor $>$ (Corbin, 1990).

Em suma, a análise requintada do imaginário promovida com finalidades religiosas, em si mesma, ao contrário do que a princípio se poderia supor, em tese nem ofende nem é ofensiva a uma perspectiva psicológicà. Ontologicamente, seria da natureza mesma do imaginário religioso que, ao revelar-se, revele a condição de ser (e o estado psíquico, portanto) do humano que o presentifica. Enfocálo por um prisma psicológico não é negar ou destruir a sua pertença ao sagrado. $\hat{E}$ ir ao encontro da forma da sua revelação, indissociável da "ilumina- 


\section{José Francisco Miguel Henriques Bairrão}

ção" de aspectos do sujeito ou comunidade humana para os quais se apresenta.

Corbin gosta de mencionar uma passagem do livro gnóstico "Atos de Pedro" em que Cristo se revela diversamente a orantes: uns vêem um ancião, outros um adolescente, outros uma criança... e todos o vêem de uma maneira própria e verdadeira.

Como as metamorfoses das teofanias dependem das pessoas que as espelham, além de revelações do divino, permitem conhecê-las.

O psicologismo não começa com a obtenção de conhecimento sobre os sujeitos humanos, proporcionada pelas suas vivências do sagrado. Principia quando o psicólogo extravasa a sua competência para emitir juízos, absolutamente inúteis e irrelevantes do ponto de vista do seu trabalho, sobre a irrealidade e não validade da experiência religiosa para além da forma psicológica em que se mostra. A redução ocorre quando o psicólogo se arvora em teólogo.

Aqui há campo para mal entendidos simétri$\cos$. Não apenas, inadvertidamente, o psicólogo pode passar a fazer hierologia ruim, como também o sujeito que, em nome da inefabilidade da vivência religiosa, se furta a conhecer os seus motivos pessoais, confessáveis ou inconfessáveis, afasta-se da vivência do sagrado, por esta se revelar mostrandoo.

\section{A criação do Criador: desejo e teofania}

Sobre o intrincado da vivência do sagrado e da experiência psíquica vale a pena transcrever uma citação por Corbin (1977, p. 165) de Abdul Karim Jîlî:

"< $<$ Sabe que quando a Imaginação ativa configura uma forma no pensamento, esta configuração e esta imaginação são criadas. Ora, o Criador existe em cada criação. Esta criação e esta figura existem em ti, e tu és o criador (al-Haqq) em relação à sua existência em ti. É pois necessário que a operação imaginativa concernente a Deus, te caiba a $t i$, mas simultaneamente Deus existe nela.... > ".

Tal como para a psicanálise, o Outro que im- porta ao místico também é, de alguma forma, uma criação do sujeito.

Psicanaliticamente, o sujeito para subsistir precisa do Outro precisa ser significado pelo Outro, depende da Palavra que lhe confere ser, sentido. Para isso atualiza o Outro, de certa forma cria-o. Mas igualmente o Deus revelado, Face do Abscôndito perante o homem e embaixador do humano perante o Insondável, é Ele próprio desejante e uma criação humana:

"A oração do gnóstico quer dizer: faz de nós, possamos ser, nós, Compadecidos, quer di$z e r,<<$ devém por nós o que eternamente o teu Desejo foi ser >>." (Corbin, 1977, p. 96)

No que Corbin denomina de oração teofânica, Deus é criado à medida do seu fiel. De certa forma, se por um lado o homem é uma criatura, o que Corbin sugere, diametralmente oposto à idéia da morte de Deus (na realidade, repise-se, uma consequiência da sua Encarnação em fato histórico e social $^{13}$ ), é, nas suas palavras, um nascimento eternal de Deus (Corbin, 1977, p. 124).

$\hat{E}$ isso que lhe permite dizer que...

“...não é o Deus pessoal que é uma etapa em direção... ao Absoluto indeterminado. $E$ ao contrário este Absoluto que é uma etapa em direção à geração, ao nascimento eterno do Deus pessoal". (Corbi, 1977, p. 198)

Esta teofania pessoal, obviamente, escapa ao alcance do projeto Genoma Humano e às verificações tecnológicas do fenótipo de alguém que tenha vivido aproximadamente há 2000 anos. Está amplamente aberta à criatividade e à necessidade humana.

Deste ponto de vista, Cristo, por exemplo, pode continuar a ter olhos azuis para uns e a revelarse negro para outros (como é o caso em seitas cristãs africanas) e cada uma destas suas manifestações, além de o apresentarem, revelam o humano que lhe é concomitante.

Em hipótese alguma a intenção de Corbin e das suas referências é relativizar a Imagem de Deus.

\footnotetext{
13 “... uma concepção na qual triunfava o paulinismo (Encarnação, theologia crucis, obsessão do pecado, maldição da carne)..."
} 
O que está em pauta é "des-absolutizar" as compreensões circunstanciais da sua forma, desautorizando a imposição de um significado estático a serviço de relações de poder entre os homens, desmerecedor da onipotência divina e da dignidade humana:

"... nossa Imaginação criadora não cria um $<$ Deus fictício $>>$. A Imagem do Deus que cria o fiel é a Imagem do Deus que revela seu ser mesmo, seu próprio ser revelado pelo $<<$ Tesouro oculto $>>^{14} \ldots E$ É então psicologicamente verdadeiro dizer que $<<$ Deus criado nas crenças $>>$ é o símbolo do Si. O Deus para quem rezamos só pode ser o Deus que se revela a nós, por nós e para nós, mas é que então em lhe rezando nós fazemos que o $<<$ Deus criado nas crenças $>>$ seja ele mesmo envolvido na Compaixão divina, quer dizer, seja existenciado, manifestado por ela. As teofanias dos $<<$ Deuses $>>$ manifestados no coração ou nas crenças são outras tantas teofanias do Deus único real (haqq haqîq $\hat{\imath}) "$. (Corbin, 1977, p. 205)

O fato de enunciados hierológicos como este não admitirem comprovação psicológica nem psicanalítica e de indubitavelmente a experiência universal dos analistas verificar, via de regra, a "falsidade" da experiência religiosa nos seus pacientes temerosos da morte, inseguros, egoístas, assustados com a vida, até mesmo incrédulos, etc., -, do ponto de vista epistemológico isso não autoriza a transformar o psiquismo em tribunal decisório da verdade sobre o sagrado. Aliás, o mesmo subterfúgio que as seitas religiosas oferecem para personalidades timoratas pode ser reproduzido por ideologias políticas e pela psicanálise, quando esta vira "doutrina" ou "orientação".

\section{Conclusões}

Os bastidores psíquicos das crenças reportamse a equívocos do sujeito quanto a si, mas não decidem da realidade do religioso enquanto tal. Não se pretende com isso, "salvar" a chamada ilusão religi-

\footnotetext{
${ }^{14}$ Referência a um célebre hadith qodsî, que, aproximadamente, afirma: $<$ Eu era um Tesouro Oculto e quis ser Conhecido ».
}

osa. Pretende-se apenas que, enquanto crença, ela se configura como ilusão, inexoravelmente, pela perspectiva de enfoque da alteridade estruturalmente inerente à psicanálise.

A partir da psicanálise podemos evidenciar as inverdades cristalizadas na psique humana, inclusive na forma de crenças religiosas. Mas há que separar o fenômeno do sagrado do fenômeno da crença, melhor, tratá-los interdependentemente, de uma forma complexa, não redutora.

A crença, fenômeno psicológico, pode ser uma mentira que o sujeito conta sobre o Outro para si mesmo. Neste caso, a redução do divino ao psíquico é promovida pelo próprio sujeito suposto religioso. É um fenômeno psíquico "seu”. Constatá-lo, como sempre, é revelador do sujeito na forma da sua verdadeira atitude perante o sagrado. Neste caso, este mostra a "sua" falsidade para este sujeito.

Como é da natureza do sagrado mostrar-se na forma da verdade relativa a cada um, desvendar nas deambulações humanas imaginárias individuais e sociais sobre o divino a presença interessada do sujeito não anula a sua dimensão de revelação do sagrado.

O estudo de epifanias contemporâneas, muito humanas e populares, permite constatar que efetivamente o imaginário religioso, enquanto sujeito, se revela revelando os sujeitos perante os quais se presentifica, perturbando-os psicologicamente nas suas entranhas mais humanas e aparentemente menos transcendentes.

Tudo indica que realmente, tal como o contam os pensadores antigos e contemporâneos que refletiram a imaginação do Outro, faz parte do seu modo de ser propor-se como Outro especular e revelador do humano e psicológico, quer seja de pessoas individuais, quer seja de comunidades. Para tê-lo como poderoso aliado da investigação psicológica é importante dar-lhe ouvidos.

\section{Referências bibliográficas}

Attar, F. ud-din. (1987). A linguagem dos pássaros. São Paulo: Attar Editorial.

Bairrão, J. F. M. H. (1996). O impossivel sujeito: implicações do tratamento do inconsciente por Lacan. Tese de Doutorado. IFCH-UNICAMP. 
26 José Francisco Miguel Henriques Bairrão

Bairrão, J. F. M. H. (2000). Aquém do princípio da psicanálise: Lacan crítico da psicologia. Olhar 3, 31-40.

Chittick C. (1989). The sufi path of knowledge. New York: State University of New York Press.

Corbin, H. (1977). L'imagination créatrice dans le soufisme d'Ibn'Arabî. Paris: Flammarion.

Corbin, H. (1981). Le paradoxe du monothéisme. Paris: Éditions de l'Herne.

Corbin, H.(1983). Face de Dieu, face de l'homme. Paris: Flammarion.

Corbin, H. (1985). Philosophie iranienne et philosophie comparée. Paris: Buchet/Chastel.

Corbin (1990). L'Iran et la philosophie. Paris: Fayard.

Corbin, H.(1996). Cuerpo espiritual y Tierra celeste. Barcelona: Ediciones Siruela.

Cortès S. J. (trad.) (1986). El Coran. Barcelona: Editorial Herder.

Izutsu, T. (1997). Sufismo e taoismo. 2 v., Madrid: Ediciones Siruela.

Lacan, J. (1966). Écrits. Paris: Éditions du Seuil.

Lacan, J. (1968). La méprise du sujet supposé savoir. Scilicet 1. Paris: Éditions du Seuil.

Lacan, J. (1975), Encore. Paris: Éditions du Seuil.

Lacan, J. (1977).L'insu que sait de l'une-bévue s'aile à mourre. Ornicar 12/3. Paris: Navarin.

Lacan, J. (1986). L'éthique de la psychanalyse. Paris: Éditions du Seuil.

Lacan, J. (inédito). D'Un Autre à l'autre.

Lewisohn, L. (org.) (1999). The heritage of Sufism. 3 v., Oxford: Oneworld.

Williams, J. A. (1980). Islamismo. Lisboa: Editorial Verbo.

\section{APOIO: FAPESP}

